\title{
Ascorbic acid and ascorbate peroxidase based defence system induced by Pseudomonas fluorescens against wilt pathogen in chickpea
}

U.K. KANDOLIYA* AND D.N. VAKHARIA

Department of Biotechnology, College of Agriculture, Junagadh Agricultural University, JUNAGADH (GUJARAT) INDIA

\begin{tabular}{|c|c|}
\hline \multicolumn{2}{|c|}{ ARITCLE INFO } \\
\hline $\begin{array}{l}\text { Received } \\
\text { Revised } \\
\text { Accepted }\end{array}$ & $\begin{array}{l}: \quad 27.10 .2014 \\
: \quad 03.02 .2015 \\
: \quad 19.02 .2015\end{array}$ \\
\hline \multicolumn{2}{|c|}{$\begin{array}{l}\text { KEY WORDS : } \\
\text { Ascorbic acid, Ascorbate peroxidase, } \\
\text { Chickpea, Fusarium oxysporum f.sp. } \\
\text { ciceri, Pseudomonas fluorescens } \\
\text { isolates }\end{array}$} \\
\hline $\begin{array}{l}\text { *Correspond } \\
\text { Email: ukka }\end{array}$ & $\begin{array}{l}\text { ing author: } \\
\text { Indolia@yahoo.com }\end{array}$ \\
\hline
\end{tabular}

\begin{abstract}
An induction of defense mechanisms against pathogens along with induction of antioxidant system is the mechanisms by which PGPR promote plant growth promotion is well known. So, the present experiment was conducted to study the plant defense system induced by PGPR bacteria Pseudomonas fluorescens against Fusarium wilt in chickpea. The results suggest that seed treatment of Pseudomonas fluorescens effective elicits activity of defense-related antioxidant system such as ascorbic acid and APX leading to improved plant resistance and reduces the mortality of chickpea plant against soil borne disease like wilt.
\end{abstract}

How to view point the article : Kandoliya, U.K. and Vakharia, D.N. (2015). Ascorbic acid and ascorbate peroxidase based defence system induced by Pseudomonas fluorescens against wilt pathogen in chickpea. Internat. J. Plant Protec., 8(1) : 86-92. 